\title{
Mortality of Great Rhododendron (Rhododendron maximum) in Virginia
}

Authored by Rachel K. Brooks, Graduate Student, School of Plant and Environmental Sciences, Virginia Tech; Mary Ann Hansen, Extension Plant Pathologist, School of Plant and Environmental Sciences, Virginia Tech; Elizabeth Bush, Extension Plant Pathologist, School of Plant and Environmental Sciences, Virginia Tech; Jon Eisenback, Professor, School of Plant and Environmental Sciences, Virginia Tech; Eric Day, Insect Identification Lab Manager, Department of Entomology, Virginia Tech

\section{Introduction}

Since 2015 Extension specialists from Virginia Tech have visited and collected plant and soil samples from several large areas of dying great rhododendron (Rhododendron maximum) in Virginia's mountainous regions (figs. 1-3). In 2016 Virginia Tech specialists met with personnel from the Virginia Department of Forestry and the U.S. Forest Service, as well as other experts, to revisit some of these sites. No consistent cause of this mortality has yet been identified. It is possible that a variety of factors are stressing the rhododendrons in these areas to a point where opportunistic pathogens or insects can successfully attack and kill them. The following information summarizes our observations and diagnostic results from four separate great rhododendron mortality sites in Virginia. This information is not equivalent to a research study, which would also include samples taken from healthy great rhododendron for comparison; however, we are confident that we have ruled out two diseases that are frequently mentioned both online and anecdotally as a cause of this mortality, specifically Phytophthora root rot and Botryosphaeria dieback.

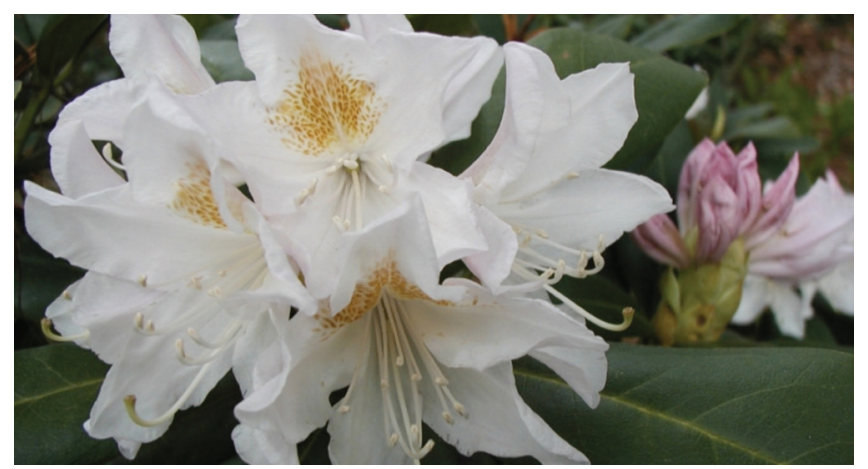

Figure 1: Great rhododendron (R. maximum) in bloom. (Photo by Dow Gardens, Bugwood.org)

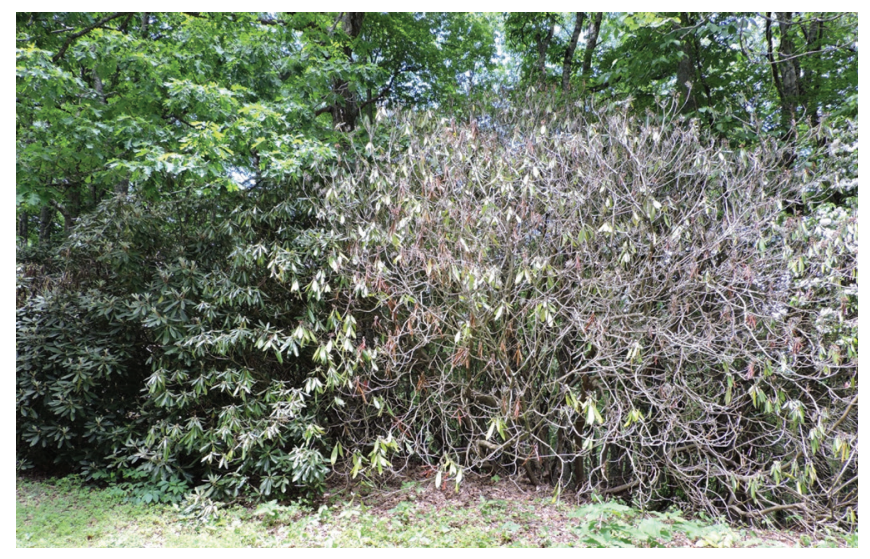

Figure 2: A symptomatic great rhododendron $(R$. maximum; right) next to a healthy great rhododendron (left) along the Blue Ridge Parkway. (Photo by Mary Ann Hansen)

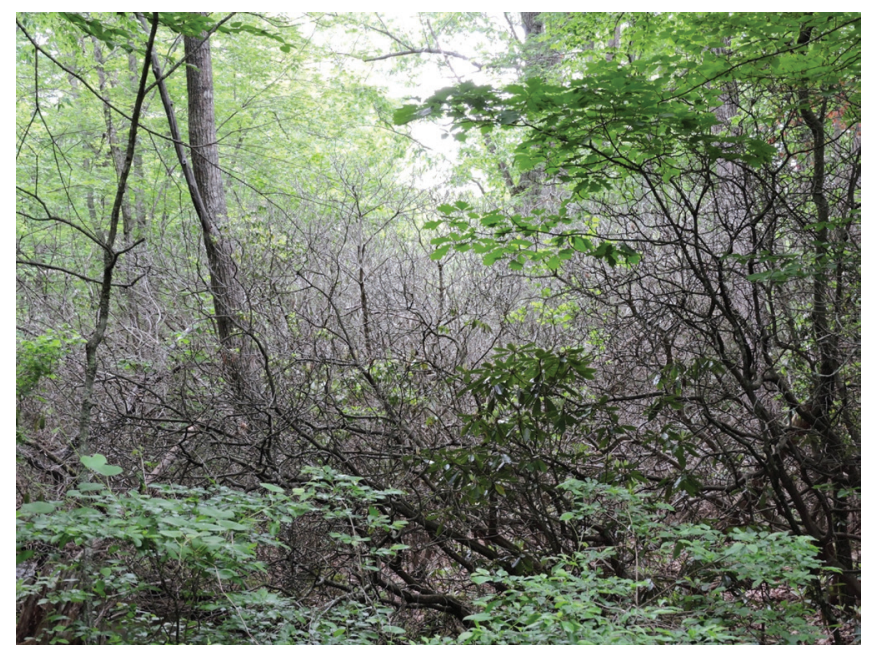

Figure 3: Dead great rhododendron (R. maximum) in the forest understory. (Photo by Elizabeth Bush) 


\section{Great Rhododendron (Rhododendron maximum)}

Great rhododendron is a common broadleaf evergreen plant found throughout Virginia's mountainous regions. It is a thicket-forming, understory shrub with iconic white or light pink flowers, most often found in moist and shady areas. Although this plant produces seeds, it typically spreads clonally by vegetative growth. It should not be confused with the Catawba rhododendron (Rhododendron catawbiense), which has smaller hairless leaves and lilac-purple flowers, and prefers locations with full or partial sun on rocky slopes and ridges.

\section{History of Rhododendron Mortality in Virginia}

Following queries from citizens regarding widespread mortality of rhododendrons along the Blue Ridge Parkway, Virginia Cooperative Extension specialists investigated several of these locations in Floyd and Patrick counties in 2015. Since then we have confirmed reports of widespread mortality of great rhododendron in Floyd, Albemarle, and Patrick counties, on both private and federal lands. Complaints of areas with similar symptoms have also been received by the Virginia Tech Plant Disease Clinic from Grayson, Carroll, and Augusta counties. Anecdotal information suggests that this mortality has been occurring on great rhododendron in multiple locations in the mountainous regions of Virginia for much longer. Outside Virginia, similar symptoms on great rhododendron have been reported in the Great Smoky Mountains National Park and the Nantahala National Forest since the 1980s (Baird et al. 2013, 2014).

\section{Symptoms and Signs}

Declining great rhododendron typically displays wilted foliage, reddish-brown discolored leaves, marginal leaf spots, thinning canopies, and dieback. Highly symptomatic or dead plants may also have discolored, stained, or water-soaked wood in lower stems or structural roots (fig. 4), insect emergence holes on affected stems, and/or white fungal mycelium under the bark near the base of the plant that is visible when bark is removed (fig. 5). Larger diameter (likely older) rhododendrons appear to be the main plants affected. Impacted rhododendrons tend to be clustered, and mortality of great rhododendron can be extensive throughout a given location. No symptoms have been observed or reported on Catawba rhododendron, including Catawba rhododendron located near affected great rhododendron.

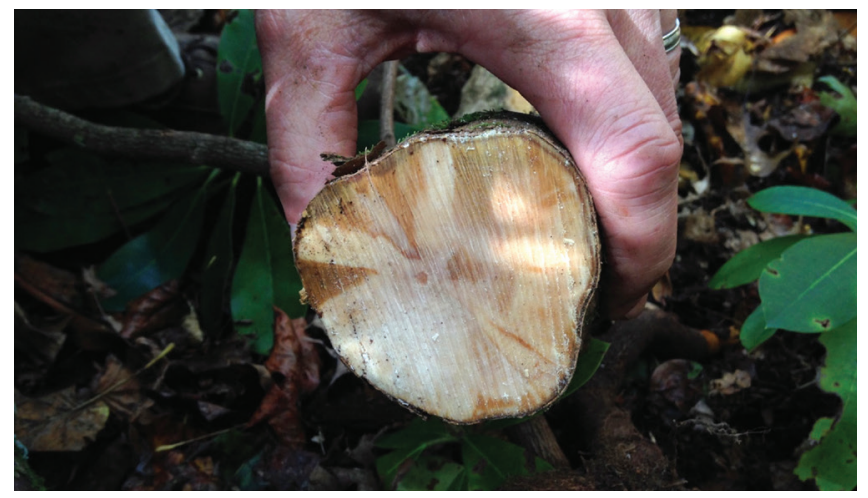

Figure 4: Cross-section of a symptomatic great rhododendron (R. maximum) stem with discolored, watersoaked wood. (Photo by Mary Ann Hansen)

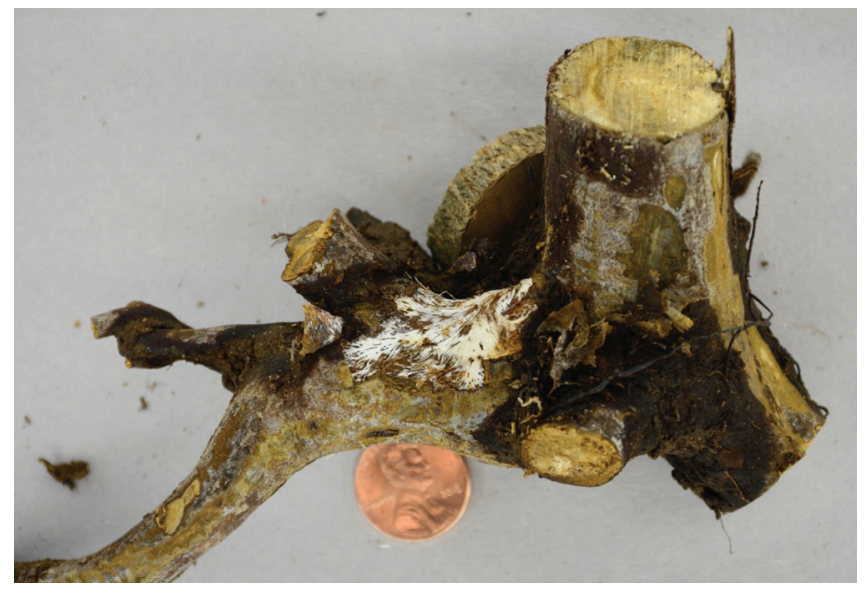

Figure 5: A white mycelial mat of the fungus Armillaria spp. at the base of an excavated, symptomatic great rhododendron (R. maximum), visible after the bark was removed. (Photo courtesy of Stephen Fraedrich)

\section{Causal Agent(s)}

Overall, no single pathogen or pest has been identified that can completely account for the observed mortality. However, several opportunistic pathogens and pests have been recovered from affected plants. Results are summarized by category, as follows.

\section{Fungi}

Several different fungi were cultured from discolored 
woody stem or root tissues of symptomatic plants collected by VCE personnel (Xeromphalina campanella, Trichoderma tomentosum, Rigidoporus sp., and Phialocephala sp.). Of these, only Phialocephala sp. was consistently recovered from plants at sites visited by VCE personnel; however, none of these fungi has ever been reported to be pathogenic on rhododendron. Although the fungus Armillaria was not observed on affected rhododendrons by VCE specialists, Ed Barnard and representatives of the U.S. Forest Service observed signs of Armillaria on declining great rhododendron plants in several locations in Virginia (Ed Barnard, personal communication). Armillaria mellea and Armillaria gallica (fungi that cause a disease commonly known as Armillaria root rot) were cultured from some of the samples they collected and identified by DNA sequencing (Stephen Fraedrich, Rabiu Olatinwo, Mee-Sook Kim, and Ned Klopfenstein, personal communication). Armillaria is a fungal genus that causes root rot in woody plants, but it is typically considered an opportunistic pathogen or saprophyte following stress on hardwoods (Wargo and Shaw 1985). No bacteria or water molds (e.g., Phytophthora species) were recovered by culturing from roots or stems of affected rhododendron at any of the four sites. Both Phytophthora root rot and Botryosphaeria dieback, which are common diseases of rhododendron species, have been ruled out as possible causes of this decline based on multiple attempts to culture these plant pathogens from symptomatic tissues..

\section{Insects}

The black stem borer (Xylosandrus germanus), a small bark beetle (fig. 6), was collected from dead great rhododendron at one of the decline sites in Virginia; however, it was not consistently associated with declining rhododendron plants. This species is known to attack stressed woody plants as an opportunistic pest (Ranger et al. 2010).

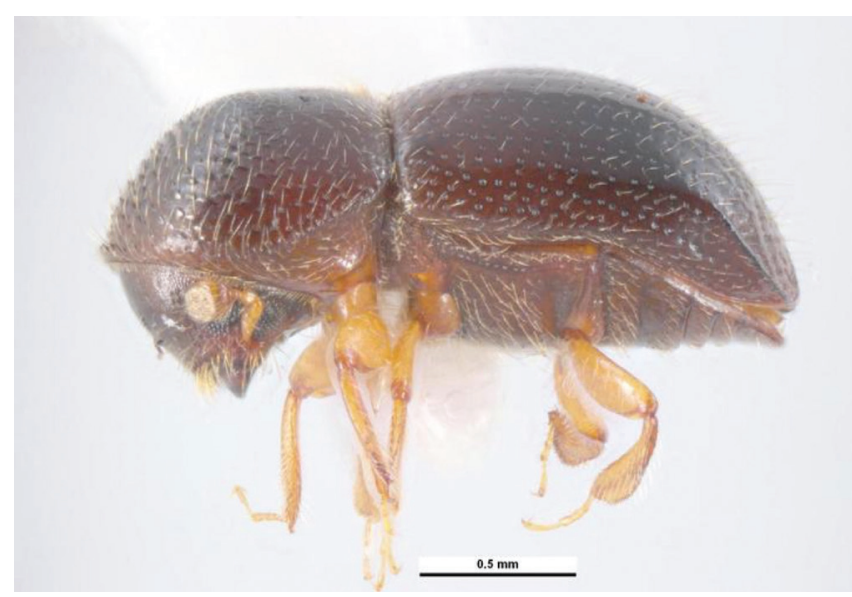

Figure 6: Black stem borer (Xylosandrus germanus). (Photo by Pest and Diseases Image Library, Bugwood.org)

\section{Nematodes}

High numbers of plant parasitic ring nematodes (Mesocriconema [fig. 7], Bakernema, Crossonema, and Xenocriconema spp.) were consistently extracted from soil at great rhododendron decline sites in Virginia. Lower levels of root-knot (Meloidogyne sp.), spiral (Helicotylenchus sp.), pin (Paratylenchus sp.), lance (Hoplolaimus sp.), and a few other plant parasitic nematode genera were also found at some sites; however, we did not sample healthy sites in Virginia for comparison. High nematode populations (including ring, root-knot, spiral, and lance nematodes) were also found in the Great Smoky Mountains National Park study in both healthy and affected plots (Baird et al. 2013, 2014). Nematode population densities necessary to cause damage to rhododendron have not been established, so it is unclear what role nematodes may play in the observed mortality.

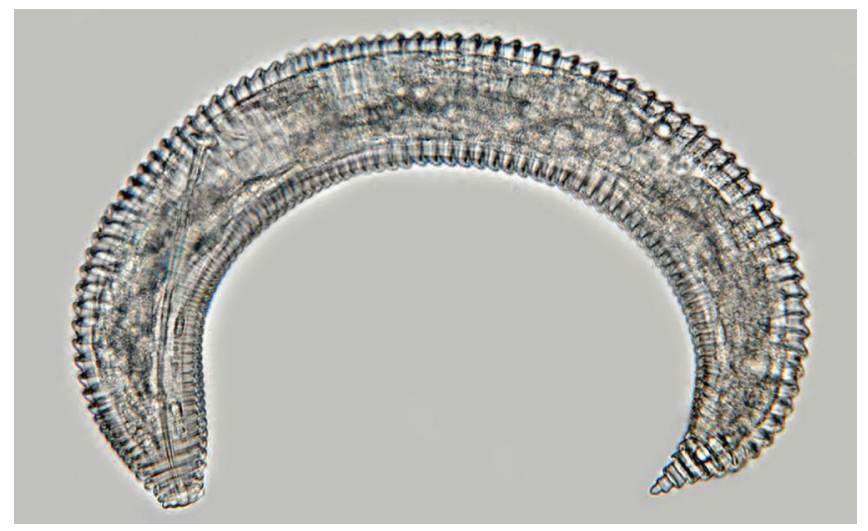

Figure 7: Ring nematode (Mesocriconema sp.) extracted from soil in the root zone of declining rhododendron plants. (Photo by Jon Eisenback) 


\section{Mammals}

At two sites in Virginia, vole tunnels (fig. 8), likely of the woodland vole (Microtus pinetorum), were observed. The woodland vole spends the majority of its time below ground consuming fibrous plant roots, so it can be difficult to associate damage by woodland voles with plant decline. Rhododendrons are not usually a preferred food species, but when vole populations are high, they may spill into less desirable habitats. It is common for voles to feed heavily in one location and then move on to another area; hence, plant symptoms may not be evident until after voles are gone (Jim Parkhurst, personal communication). However, vole tunnels were not observed at all sites; therefore, we do not think voles are a primary factor in rhododendron mortality.

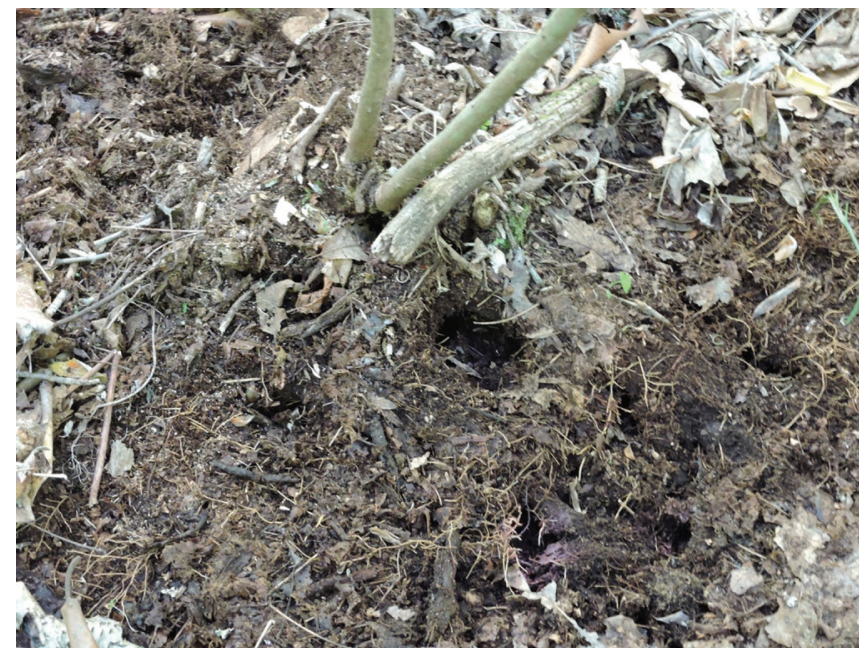

Figure 8: Vole tunnels near the base of a symptomatic great rhododendron (R. maximum). (Photo by Elizabeth Bush)

\section{Site and Environmental Conditions}

Soil samples were collected for $\mathrm{pH}$ testing at two of the symptomatic sites in Virginia; $\mathrm{pH}$ measurements ranged from 3.9 to 4.9 , a range that is acceptable for great rhododendron. Nutrient analysis was not performed on these samples. Baird et al. $(2013,2014)$ tested soil nutrient levels at the sites they studied but reported no clear trends in nutrient availability with respect to great rhododendron mortality. However, Baird et al. (2013) did report an increase in dieback after several years of drought. The progression of decline with respect to weather conditions has not been investigated in Virginia.

\section{Concluding Remarks}

In the areas with high mortality of great rhododendron that we examined, we found no single factor that could definitively account for the symptoms observed. It is possible that the mortality is not caused by a single pathogen or pest, but is a result of a complex of abiotic and biotic factors (e.g., environmental stresses that predispose rhododendron to attack by opportunistic pathogens and/or pests). This would be similar to a disease complex called "oak decline," in which long-term factors (e.g., age, climate changes, and site quality) and short-term factors (e.g., insect defoliation, drought, and frost) weaken oak trees and allow opportunistic insects and pathogens to invade and kill them. In areas with oak decline, crowding, older trees, and low species diversity are also factors that are associated with tree mortality (Oak 2005). A similar situation could be involved in the mortality of great rhododendron in the Appalachian Mountains in Virginia.

In the early 20th century, disturbances, such as logging and chestnut blight, and changes in forest management, including fire suppression, allowed great rhododendron to significantly expand its presence in the forest understory in many areas of the Appalachians (Baker and Van Leer 1998; Elliott and Vose 2012). As great rhododendron matures, it can suppress growth of other plant species, thus leading to a near monoculture of this species in the understory (Anderson 2008). In the areas we visited, great rhododendron was, in fact, the predominant understory species, and overall plant diversity was low. Although we did not determine the average age of the stands we visited, the age of one dead great rhododendron plant was estimated at 67 years, based on the number of annual rings; most great rhododendron plants in these stands had similar stem diameters. In a study conducted in the mountains of North Carolina, researchers found that great rhododendron can live up to 120 years, but the average age in areas favorable for growth was about 60 years (Elliott and Vose 2012). The land use history in the areas we visited may have led to a large cohort of similarly aged mature rhododendron in these locations (Ralph Lutts, personal communication).

Mature plants with extensive root systems place a high demand on available water and nutrients and may be more sensitive to periods of environmental stress. For example, in forest areas exhibiting oak decline, mature 
oaks in crowded sites were more sensitive to moisture stress during drought and less able to recover when moisture was again abundant. The stressed oaks in these sites were more prone to attacks by opportunistic fungi, including Armillaria spp., and opportunistic insect pests (Clatterbuck 2006). Comparably, most of the dead and dying rhododendron plants we observed appeared to be mature or approaching maturity, with opportunistic insects and pathogens present in some of the sampled plants.

The mortality of great rhododendron along the Blue Ridge Parkway and other areas of Virginia's scenic mountainous regions is dramatic and can be alarming to those observing it for the first time. In the past the cause of these symptoms has been erroneously attributed to either Phytophthora root rot or Botryosphaeria dieback, two diseases that commonly cause dieback of rhododendron species in landscape settings. We have definitively ruled out both of these diseases as possible causes of the widespread mortality we observed: neither Phytophthora root rot nor Botryosphaeria dieback were found to be associated with any of the great rhododendron samples we collected at any of the sites. Our results support earlier findings from Baird et al.'s (2003 \& 2004) extensive studies of rhododendron mortality in the Great Smoky Mountains in Tennessee and the Nantahala National Forest in North Carolina, as well as results from forest surveys conducted by the U.S. Forest Service from Virginia to Georgia in 2004-06 (Steve Oak, personal communication). We speculate that widespread mortality of great rhododendron in the mountainous regions of Virginia is due to environmental stress, followed by opportunistic pests and pathogens that attack stressed plants, rather than to one single primary pest or pathogen. Thus, we will likely continue to see decline in mature stands of great rhododendron in areas of the forest that experience prolonged periods of environmental stress.

\section{Acknowledgements}

We would like to thank all of those who visited the rhododendron mortality sites and/or contributed their expertise, including Stephen Fraedrich, Albert Mayfield, Bryan Mudder, Rabiu Olatinwo, and Steve Oak (retired) (USFS Southern Research Station); Mee-Sook Kim (USFS Pacific Northwest Research Station); and Ned Klopfenstein (USFS Rocky Mountain Research Station); Lori Chamberlin, Katlin
Mooneyham, Jason McGhee, Kevin Keith, Donnie Garman, and Dennis Anderson (Virginia Department of Forestry); Jonathan Vest (Virginia Cooperative Extension); Jim Parkhurst (Virginia Tech Department of Fish and Wildlife Conservation); Robert J. Webster (National Park Service); Ed Barnard (retired) (Florida Department of Agriculture and Consumer Services, Florida Forest Service); and Ralph Lutts (Visiting Scholar, Virginia Tech Department of History).

\section{References}

Anderson, Michelle D. 2008. "Rhododendron Maximum." Fire Effects Information System website. U.S. Department of Agriculture, Forest Service, Rocky Mountain Research Station, Fire Sciences Laboratory. https://www.fs.fed.us/ database/feis/plants/shrub/rhomax/all.html.

Baird, R., A. Wood-Jones, J. Varco, C. Watson, W. Starrett, G. Taylor, and K. Johnson. 2013. “All Taxa Biodiversity Inventory Survey of Select Soil and Plant Ecological Parameters Associated with Rhododendron Decline in the Great Smoky Mountains and Surrounding Areas." Southeastern Naturalist 12 (4): 703-22.

Baird, R., A. Wood-Jones, J. Varco, C. Watson, W. Starrett, G. Taylor, and K. Johnson. 2014. "Rhododendron Decline in the Great Smoky Mountains and Surrounding Areas: Intensive Site Study of Biotic and Abiotic Parameters Associated with the Decline." Southeastern Naturalist 13:1-25.

Baker, T. T., and D. H. Van Leer. 1998. "Relations Between Density of Rhododendron Thickets and Diversity of Riparian Forests." Forest Ecology and Management 109:21-32.

Clatterbuck, W. K., and B. W. Kauffman. 2006. Managing Oak Decline. Professional Hardwood Note No. 1. University of Tennessee Extension Publication SP675.

Elliott, K. J., and J. M. Vose. 2012. “Age and Distribution of an Evergreen Clonal Shrub in the Coweeta Basin: Rhododendron maximum L." The Journal of the Torrey Botanical Society 139 (2): 149-66. 
Oak, S. 2005. "Forest Health Impacts of the Loss of American Chestnut." In Restoration of American Chestnut to Forest Lands: Proceedings of a Conference and Workshop, edited by K. C. Steiner and J. E. Carlson, 21-29. Conference held May 4-6, 2004, Asheville, NC. Natural Resources Report NPS/NCR/CUE/NRR - 2006/001. Washington, DC: National Park Service.

Ranger, C. M., M. E. Reding, A. B. Persad, and D. A. Herms. 2010. "Ability of Stress-Related Volatiles to Attract and Induce Attacks by Xylosandrus germanus and Other Ambrosia Beetles." Agricultural and Forest Entomology 12 (2): 177-85.

Wargo, P. M., and C. G. Shaw III. 1985. "Armillaria Root Rot: The Puzzle Is Being Solved." Plant Disease 69 (10): 826-32. 